\title{
Breath methane and large bowel cancer risk in contrasting African populations
}

\author{
I SEGAL, A R P WALKER, S LORD, AND J H CUMMINGS \\ From the Gastroenterology Unit, Baragwanath Hospital and University of the Witwatersrand, Human \\ Biochemistry Research Unit, South African Institute for Medical Research, South Africa, and MRC Dunn \\ Clinical Nutrition Centre, Cambridge
}

SUMMARY Breath methane has been measured in 1016 people from four populations resident in Southern Africa which experience widely different risks of bowel cancer and other colonic diseases. Highly significant differences in the proportion of subjects with detectable methane in breath were found; \% producers - rural black 84, urban black 72, white 52, Indian $41\left(\chi^{2} 121\right.$ p<0.001 3 df). There was a slight preponderance of female producers over male (female producers $63 \%$, males $57 \%$ ) and an age trend with fewer producers in the older age groups in the urban blacks and Indians, these comparisons being significant when tested by stepwise logistic regression analysis. Bowel cancer risk, determined from a variety of sources, was lowest in rural blacks, greatest in whites, with intermediate rates for urban blacks and Indians. Methane production in the human colon shows significant interethnic differences but which bear no relation to bowel cancer risk in these populations.

Although it has been known for more than 150 years that methane is produced in the human large intestine, nevertheless the physiology and importance of methanogenesis in man remains something of an enigma. Methane is one of the principal end products of fermentation in anaerobic systems such as the reumen,' whilst in man active fermentation occurs in the large intestine ${ }^{2}$ and methanogenic bacteria such as Methanobrevibacter smithia have been found in faeces. ${ }^{3-7}$ Methane installed into the human colon rapidly appears in breath ${ }^{8}$ as do other fermentation gases such as hydrogen. ${ }^{9}$ In most published reports of population studies, however, only $35-61 \%$ of healthy adult subjects have detectable methane in their breath ${ }^{80-17}$ although two reports give higher values. ${ }^{18-19}$ In detailed studies by Levitt and Ingelfinger of individuals, using intestinal perfusion with air or nitrogen, about half of the subjects tested showed no sign whatsoever of methane evolution in the colon. ${ }^{9}$

Address for correspondence: Professor I Segal, Dept of Medicine, Baragwanath, PO Bertsham, 2013, South Africa.

Received for publication 16 November 1987.
A group of people with unexpectedly high breath methane levels are those with large bowel cancer. In two separate studies 80 and $91 \%$ of these patients had methane detectable in their breath and the proportion of methane producers was also increased in patients with premalignant conditions of the bowel such as polyps. ${ }^{1314}$ Physiologically methane production is associated with slow gut transit time, small faecal weight, and high faecal $\mathrm{pH}^{20}$ although these differences in faecal weight have not been found consistently. ${ }^{12}$ is

Many clues to the aetiology of bowel disease have come from population studies, especially those in Africa where major differences in the risks of bowel cancer, appendicitis, and diverticular disease exist ${ }^{21-24}$ often in people living in closely related geographical areas. We have therefore measured breath methane in four population groups in Southern Africa who show marked differences in bowel disease risk in the belief that the group with the lowest risk of bowel disease and fastest gut transit time would have least methane in their breath and vice versa. The results show that there are major differences in methane producer status amongst the populations, but these do not relate to bowel cancer risk. 


\section{Methods}

\section{SUBJECTS}

One thousand and sixteen outwardly healthy subjects from four population groups were studied (Table 1). One hundred rural black adults were volunteers from the villages of Hekpoort and Pankop situated in western and northern Transvaal 80 and $120 \mathrm{~km}$ respectively from Johannesburg. One hundred pupils attending the village schools also participated. One hundred and forty eight urban blacks were recruited from the townships of Alexandra and Soweto and 120 pupils from schools in these towns; 134 whites were staff and students from Baragwanath Hospital and the South African Institute of Medical Research in Johannesburg, and 86 pupils were recruited from local Catholic Convent schools; the Indians, 128 adults and 200 schoolchildren were resident in Johannesburg and Lenasia. All the subjects were fit and none had been taking antibiotics or laxatives for three months before the study. Smoking was not allowed for one hour before breath samples were taken.

\section{METHANE}

Duplicate end expiratory breath samples were collected via a Wiggins end expiratory breath sampler ${ }^{25}$ into $20 \mathrm{ml}$ plastic syringes. Methane concentration was determined by gas chromatography using a Pye Unicam PU-4500 equipped with a hydrogen ionisation detector. The carrier gas was nitrogen. A sample of room air was taken at the time of each breath sample and the value (usually in the range $1.7-2.2$ parts per million (ppm)) was subtracted from the average level of the duplicate breath samples. Methane producers were defined as those producing more than $1 \mathrm{ppm}$ of methane above the level in the ambient air. ${ }^{10}$

This study was approved by the Ethical Committee of the Medical School the University of the Witwatersrand, Johannesburg.

\section{BOWEL DISEASE STATISTICS}

Because of the difficulties in obtaining morbidity data for some bowel diseases, the analysis has been limited to large bowel cancer. Data have been compiled from Cancer Incidence in Five Continents, Vol II and $\mathrm{III}^{2627}$ and various published and unpublished sources. ${ }^{21228-36}$

\section{STATISTICAL ANALYSIS}

Statistical analysis was carried out using SPP (a statistical package for personal computers - by P Royston, Supersoft Ltd, Harrow, UK). Because of the distribution of age and breath methane data all values were transformed to $\log _{e}$. Intergroup differ- ences were assessed by analysis of variance and frequencies of methane producer versus nonproducer status by $\chi^{2}$. The relation of age, location and sex to methane producer status was tested by stepwise logistic regression analysis using GENSTAT. Results are given as median and range unless otherwise stated.

\section{Results}

The total population of 1016 subjects was roughly equally divided between men (511) and women (505) and between schoolchildren (499) and adults (517) (Table 1). Median age of adults was 30 (range 14-80) years and adolescents $16(14-21)$. There was a greater proportion of the population over the age of 45 amongst the whites but the oldest subjects $(70+)$ were in fact all rural blacks. Analysis of variance for age showed a significant difference amongst the adult population (F 6.48, p $\left.4.9 \times 10^{-4}\right)$ mainly because the white males who were slightly older (median 32 years). Modifying this group by excluding some of the older subjects made no difference to the conclusions, however, and interpretation of any of the data so they have been left in.

For the whole population $60 \%$ had detectable methane in breath (greater than 1 ppm above background), but as Table 2 shows there were highly significant differences amongst the four ethnic groups. Seventy two to $84 \%$ of black populations were producers, while only $52 \%$ of the whites and $41 \%$ of the Indians were.

A more detailed examination (using stepwise logistic regression) of methane producer status in relation to age, location, and sex (Fig. 1) showed that for all subjects the relative risk of being a producer was in the order rural black, urban black, white, Indian and was greater in the younger age groups, this age trend being significant in the urban blacks and Indians. More women than men were producers; $57 \%$ men and $63 \%$ women $\left(\chi^{2} 3 \cdot 8, p=0.041 \mathrm{df}\right)$ but breath methane concentrations were similar; 11.1 $(1 \cdot 1-55 \cdot 1) \mathrm{ppm}$ men, $11.95(1 \cdot 1-56 \cdot 1) \mathrm{ppm}$ women.

Table 1 Age, sex, and number of subjects

\begin{tabular}{llllll}
\hline & Rural black & \multicolumn{2}{l}{ Urban black } & White & Indian \\
\hline$n$ & Total (M/F) & Total (M/F) & Total (M/F) & Total (M/F) \\
School pupils & $100) 53 / 47)$ & $120(58 / 62)$ & $86(44 / 42)$ & $200(95 / 105)$ \\
Adults & $100(50 / 50)$ & $148(75 / 73)$ & $134(67 / 67)$ & $128(65 / 59)$ \\
Age* & & & & \\
School pupils & $16(14-21)$ & $17(14-21)$ & $16(14-18)$ & $16(14-18)$ \\
Adults & $28(16-80)$ & $28(18-57)$ & $31 \cdot 5(16-68)$ & $31(14-58)$ \\
\hline
\end{tabular}

${ }^{*}$ Median (range). 
Table 2 Breath methane: all subjects

\begin{tabular}{llll}
\hline Population & $\begin{array}{l}\% \text { Producers } \\
(n)\end{array}$ & $\begin{array}{l}\% \text { Non-producers } \\
(n)\end{array}$ & $\begin{array}{l}\text { Breath methane } \\
\text { (Median+range) }\end{array}$ \\
\hline Rural Black & $84(168)$ & $16(32)$ & $15 \cdot 5(1 \cdot 1-56 \cdot 1)$ \\
Urban black & $72(193)$ & $28(75)$ & $10 \cdot 6(1 \cdot 1-48 \cdot 2)$ \\
White & $52(114)$ & $48(106)$ & $10 \cdot 0(1 \cdot 1-44 \cdot 4)$ \\
Indian & $41(133)$ & $59(195)$ & $8 \cdot 5(1 \cdot 1-52 \cdot 3)$ \\
All cases & $60(608)$ & $40(408)$ & $11 \cdot 4(1 \cdot 1-56 \cdot 1)$ \\
\hline
\end{tabular}

$\chi^{2} 121 \cdot 8 \mathrm{p}<0.0013 \mathrm{df} ;$ ANOVAR F $12.2 \mathrm{p}<0.001$.

The concentration of methane in breath followed the same order as methane producer status amongst the various populations (Table 2). Median breath methane for all producer subjects was 11.4 (1.1-56.1) $\mathrm{ppm}$. There was no general relationship between age

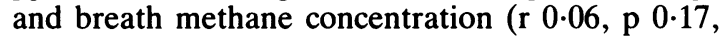
$\mathrm{n}=608$ ) despite the significant association with methane producer status and age (Fig. 1). Breath methane levels were highest in rural black school children; $17 \cdot 7(1 \cdot 2-51 \cdot 0) \mathrm{ppm}, 95 \%$ of whom were producers, and lowest in Indian adults; 5.8 (1.4$52 \cdot 3) \mathrm{ppm}$, of whom $21 \%$ were producers. Figure 2 shows the distribution of breath methane levels in

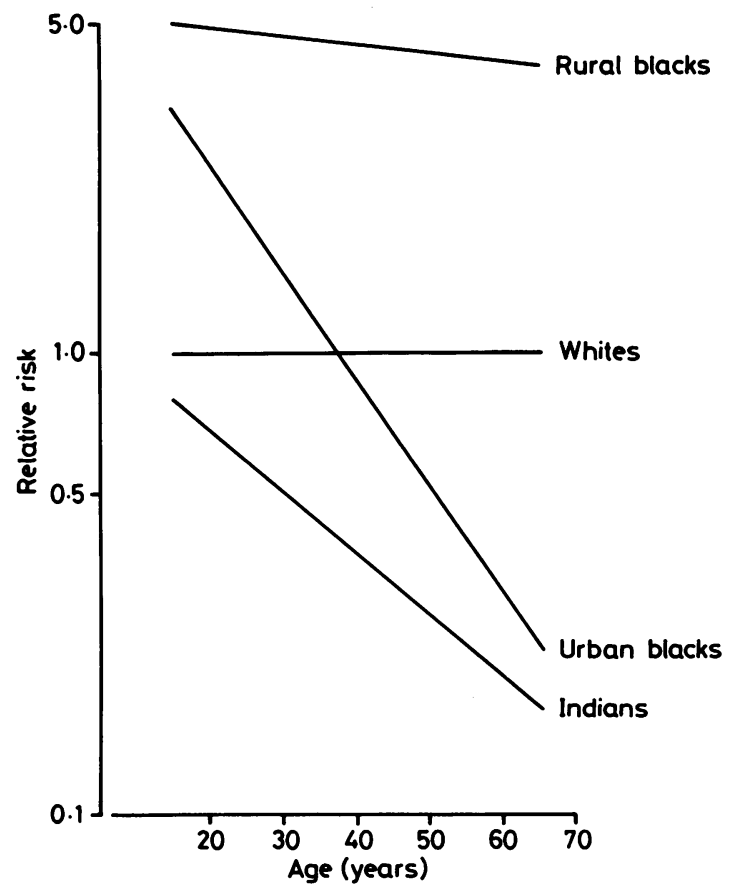

Fig. 1 Relative risk of being a methane producer in relation to age and location of all subjects. Slope of line $(\% \mathrm{per}$ year): rural black $-0 \cdot 5$; urban black $-6 \cdot 4$; white $+0 \cdot 1$; Indian -5.8). each population group. Distributions were all skewed but similar in each ethnic group.

\section{Discussion}

The findings in the present study show widely differing proportions of methane producers in different ethnic groups but do not support the view that methane production in the large intestine is a risk factor for large bowel cancer.

Table 3 summarises current information on the mortality and incidence of colonic and rectal cancer in the four population groups. Although there are a number of problems in estimating the reliability of these data, nevertheless some general conclusions can be drawn. Bowel cancer is uncommon in both urban and rural blacks as observed by the authors of many papers on the subject. ${ }^{2122282931-333536}$ As a proportion of all cancer deaths in the rural populations bowel is between one fifth and one tenth less common than in the United Kingdom. Incidence and mortality data for urban blacks show rates that are again about one tenth of those seen in England and Wales and in United States populations whilst in the white population of South Africa rates are much higher and similar to those in the west. Firm details for the Indian population are more difficult to obtain, probably because they are only a small fraction of the total population $(0.9 \mathrm{M}$ of a total of $26 \mathrm{M})$. Amongst Indians rates appear to be intermediate between whites and blacks. These data do not relate in any consistent way to methane status. The high proportion of methane producers found in patients with

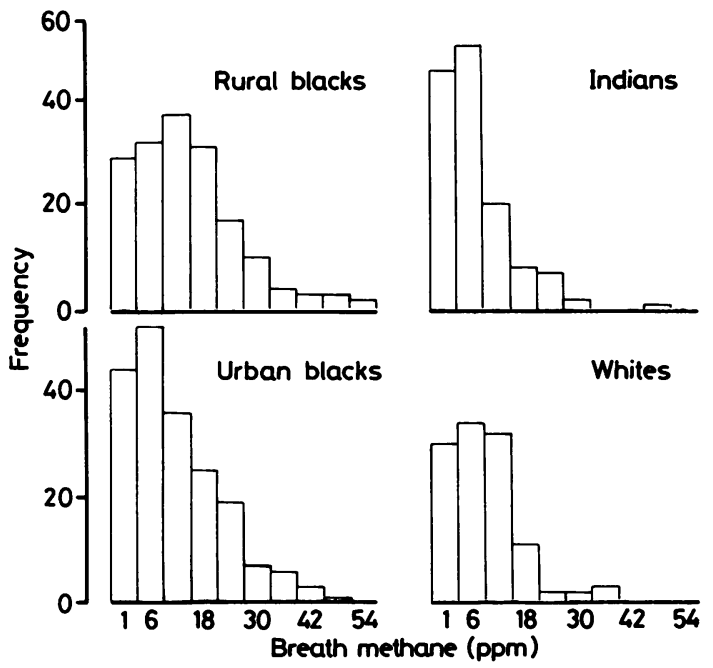

Fig. 2 Frequency distribution of breath methane concentration (ppm) for all ages (producers only). 
Table 3 Large bowel cancer (colon+ rectum) incidence and mortality in South African populations

\begin{tabular}{|c|c|c|c|c|c|}
\hline $\begin{array}{l}\text { Population } \\
\text { description }\end{array}$ & Age & $\begin{array}{l}\text { Incidence }(\text { In }) \text { or } \\
\text { mortality }(M o)\end{array}$ & Rate/100000 & Sex & Source \\
\hline \multicolumn{6}{|l|}{ Rural black } \\
\hline Rural Bantu & All ages & In & $\begin{array}{l}7 \cdot 5 \% \text { of all cancers } \\
0 \cdot 8 \% \text { of all cancers }\end{array}$ & $\begin{array}{l}\mathbf{M} \\
\mathbf{F}\end{array}$ & Higginson and Oettlé $1960^{21}$ \\
\hline $\begin{array}{r}\text { Shangaan, Swazi, and } \\
\text { Sotho, N Transvaal }\end{array}$ & All ages & In & $\begin{array}{l}2.4 \% \text { of all cancers } \\
\text { No recorded cases }\end{array}$ & $\begin{array}{l}\mathbf{M} \\
\mathbf{F}\end{array}$ & Sutherland $1960^{36}$ \\
\hline 'Rural' & All ages & In 'rare' & $\begin{array}{l}1-2 \cdot 5 \% \text { of all } \\
\text { cancers }\end{array}$ & & Burkitt $1971^{33}$ \\
\hline \multicolumn{6}{|l|}{ Urban Black } \\
\hline Johannesburg & All ages & In & $\begin{array}{l}1 \cdot 5 \\
2 \cdot 3\end{array}$ & $\begin{array}{l}\mathbf{M} \\
\mathbf{F}\end{array}$ & UICC $1960^{26}$ \\
\hline Bantu-Johannesburg & All ages & Mo & $\begin{array}{l}2 \cdot 3 \% \text { of all cancers } \\
3 \cdot 1 \% \text { of all cancers }\end{array}$ & $\begin{array}{l}\mathbf{M} \\
\mathbf{F}\end{array}$ & Higginson and Oettlé $1960^{21}$ \\
\hline Bantu-Johannesburg & All ages standardised (African) & $\begin{array}{l}\text { In } \\
\text { In }\end{array}$ & $\begin{array}{l}2 \cdot 0 \\
3 \cdot 5\end{array}$ & $\begin{array}{l}\mathbf{M} \\
\mathbf{F}\end{array}$ & Higginson and Oettlé $1966^{35}$ \\
\hline Cape Province & Age standardised (world) & In & $\begin{array}{l}6 \cdot 9 \\
8 \cdot 8\end{array}$ & $\begin{array}{l}\mathbf{M} \\
\mathbf{F}\end{array}$ & UICC $1970^{27}$ \\
\hline Natal & Age standardised (world) & In & $\begin{array}{l}3 \cdot 1 \\
6 \cdot 0\end{array}$ & $\begin{array}{l}\mathbf{M} \\
\mathbf{F}\end{array}$ & UICC $1970^{27}$ \\
\hline Soweto & 45 cases over 12 year period ( 1954 & -1966) from popula & ation of 600000 & & Bremner and Ackermann $1970^{32}$ \\
\hline Johannesburg & $35-64$ 'age standardised' & Mo & $6 \cdot 4$ & $\mathbf{M}$ & Burkitt $1971^{33}$ \\
\hline Soweto & All ages & In & $\begin{array}{l}1.53 \\
1.0\end{array}$ & $\begin{array}{l}\mathbf{M} \\
\mathbf{F}\end{array}$ & Isaacson et al $1978^{31}$ \\
\hline & $60 \mathrm{yr}+$ & In & $\begin{array}{l}7 \cdot 71 \\
7 \cdot 51\end{array}$ & $\begin{array}{l}\mathbf{M} \\
\mathbf{F}\end{array}$ & \\
\hline Soweto & $\begin{array}{l}\text { All ages } \\
45-64 \\
65+\end{array}$ & $\begin{array}{l}\text { Mo } \\
\text { Mo } \\
\text { Mo }\end{array}$ & $\begin{array}{l}0 \cdot 8 \\
2 \cdot 2 \\
6 \cdot 5\end{array}$ & $\begin{array}{l}M+F \\
M+F \\
M+F\end{array}$ & Segal et al $1981^{28}$ \\
\hline \multicolumn{6}{|l|}{ Indian } \\
\hline 'Asians' & $\begin{array}{l}\text { Age standardised to US } \\
\text { population }\end{array}$ & Mo & $\begin{array}{r}9 \cdot 7 \\
10 \cdot 3\end{array}$ & $\begin{array}{l}\mathbf{M} \\
\mathbf{F}\end{array}$ & Oettlé $1964^{22}$ \\
\hline Natal & Age standardised (world) & In & $\begin{array}{r}6 \cdot 2 \\
17 \cdot 9\end{array}$ & $\begin{array}{l}\mathbf{M} \\
\mathbf{F}\end{array}$ & UICC $1970^{27}$ \\
\hline $\begin{array}{l}\text { 'Asians' } \\
\text { Durban }\end{array}$ & $\begin{array}{l}\text { Age standardised (world) } \\
6 \text { deaths in 1983. Total population }\end{array}$ & $\begin{array}{l}\text { Mo } \\
450000\end{array}$ & $5 \cdot 0$ & $\mathrm{M}+\mathrm{F}$ & $\begin{array}{l}\text { Bradshaw and Harrington } 1975^{29} \\
\text { City of Durban } 1983^{34}\end{array}$ \\
\hline $\begin{array}{l}\text { Whites } \\
\text { National }\end{array}$ & $\begin{array}{l}\text { Age standardised to US } \\
\text { population }\end{array}$ & Mo & $\begin{array}{l}17 \cdot 4 \\
16 \cdot 1\end{array}$ & $\begin{array}{l}\mathbf{M} \\
\mathbf{F}\end{array}$ & Oettlé $1964^{22}$ \\
\hline Cape Province & Age standardised (world) & In & $\begin{array}{l}18 \cdot 3 \\
22 \cdot 3\end{array}$ & $\begin{array}{l}\mathbf{T} \\
\mathbf{F}\end{array}$ & UICC $1970^{27}$ \\
\hline $\begin{array}{l}\text { National } \\
\text { Johannesburg }\end{array}$ & $\begin{array}{l}\text { Age standardised (world) } \\
\text { All ages } \\
45-64 \\
65+\end{array}$ & $\begin{array}{l}\text { Mo } \\
\text { Mo } \\
\text { Mo } \\
\text { Mo }\end{array}$ & $\begin{array}{l}9-12 \\
13 \cdot 1 \\
24 \cdot 5 \\
55 \cdot 0\end{array}$ & $\begin{array}{l}M+F \\
M+F \\
M+F \\
M+F\end{array}$ & $\begin{array}{l}\text { Bradshaw and Harrington } 1975^{29} \\
\text { Segal } \text { et al } 1981^{28}\end{array}$ \\
\hline
\end{tabular}

Total large bowel cancer incidence and mortality data for rural and urban black, white, and Indians in South Africa covering the period 1953-1971 approximately. ${ }^{21} 26-36$ For comparison: England and Wales (1985) colon and rectal cancer accounted for $11 \cdot 2 \%$ of all cancer deaths in men, and $13.5 \%$ in women. ${ }^{37}$ Average age standardised (world) incidence for six cancer registries in the UK (Birmingham, Oxford, Sheffield, South West, Liverpool, and Ayrshire) 1968-1972 is $29 \cdot 8 / 100000$ for men, and $23 \cdot 8$ for women (colon + rectum). ${ }^{38} 39$

bowel cancer by Haines $e t a l^{13}$ and by Pique $e t a l^{14}$ of $80 \%$ and $91 \%$ respectively must represent a change from normal due to the cancer rather than leading to its cause. This view is supported by the observations that methane producer status returns to that of the control population after surgery to remove the tumour. ${ }^{14}$

Breath methane data in the present study show marked ethnic differences and an association with age and sex. There is no consistency in the literature at present with regard either to the effects of age or sex. In three studies ${ }^{81015}$ no effect of sex was seen whilst in three others more women were producers than men. ${ }^{11} 1316$ No study has convincingly shown men to be greater producers. With regard to age in adults again three studies ${ }^{810}$ is show no effect whilst in the study of Haines et $^{a l^{40}}$ involving 1398 subjects there was an increase in the proportion of methane producers with age, the opposite of the present study. This was, however, entirely an urban population in 
northwest London. Young children usually produce less methane than adults. ${ }^{1017} 19$

Few interethnic comparisons have been made. It is worth noting, however, that whilst Drasar et al ${ }^{19}$ observed that $77 \%$ of 159 adult rural Nigerians were producers, Pitt et al ${ }^{11}$ found only $45 \%$ of black hospital staff in Toronto, Canada, were producers (total $n=69$ ) and similarly Haines et $a l^{40}$ observed $43 \%$ of black men and $33 \%$ of black women in a total sample of 99 persons in northwest London were producers. Pitt et al also looked at other ethnic groups in Toronto and reported $24 \%$ of orientals, $48 \%$ of whites, and $32 \%$ of Indians were methane producers.

These interethnic comparisons are not as discordant as might seem at first sight. In general up to $61 \%$ (mostly $40-50 \%$ ) of healthy urbanised adults of any race are methane producers whilst for rural blacks the proportion is $77-84 \%$. Urbanised blacks in Africa are lower (72\%) than rural blacks $(84 \%)$ and approach the same proportion as whites $(52 \%)$ in long established urban populations which have become fully accultured - for example, Toronto and northwest London. In Soweto, however, which retains a more traditional diet and lifestyle the ethnic differences remain. Indians seem invariably to be low at $31 \%$ or less. How can these differences be explained?

Methane is produced in the gastrointestinal tract, both rumen' and caecum ${ }^{41}$ by oxidation of hydrogen by methanogenic bacteria. This process produces energy for the bacteria and an overall mechanism for terminal electron disposal thus permitting continued breakdown of fermentation intermediates to acetic acid. Methanogenesis is an example of interspecies hydrogen transfer which allows carbohydrate and amino acid fermenting species to oxidise more completely their substrates. The net effect of hydrogen oxidation is to increase substrate use and shift fermentation to more oxidised end products. ${ }^{42}$

Despite the absence of methane in the breath of many people, methanogenic bacteria can be cultured from faeces in the majority ${ }^{346}$ and methane production from faecal cultures is almost universal in some studies $^{1543}$ regardless of breath concentrations, although reasonable concordance between faecal incubation and breath methane status has been observed by Levitt and Ingelfinger ${ }^{9}$ and Bjorneklett and colleagues. ${ }^{8}$ Wolin's group ${ }^{6}$ has suggested that methane appears in breath only when the numbers of methanogenic bacteria in the colon reach a critical level, about $10^{8} / \mathrm{g}$ dry weight contents, and that carriage of these bacteria is probably universal. Dividing a population into producers and nonproducers may therefore be artefactual as everyone is a potential producer. What is unknown at present are the factors controlling the number of methanogens and the amount of methane they produce.

Methanogenesis may be promoted by ensuring adequate hydrogen production from fermentation that is, having sufficient substrate for fermentation available, by slow transit time $\mathrm{e}^{20}$ and mechanical factors as suggested by Weaver et al.$^{6}$ Inhibition could arise through competition from sulphate reducers and the presence of sulphate ${ }^{42}$ or nitrate. ${ }^{44}$ From the present study, however, slow transit would not seem to be an essential feature because whole gut transit time is known to be much faster in the populations (urban and rural blacks) which produce most methane. ${ }^{45-46}$ Conditions which favour methane production and their attendant health implications require further study.

The authors wish to acknowledge help in field studies given by Mesdames F A Cassim, $\mathrm{K}$ Devchand, M Kadwa, C Walker, M M Verardi, Sister G M Letsholo, and $\mathrm{Mr} \mathrm{J}$ Kolobe. Dr Tim Cole gave valuable help and advice in the statistical handling of the data. The work was supported by the National Cancer Association of South Africa, the Medical Research Council and the Chairman's Fund, AngloAmerican and De Beers Corporation.

\section{References}

1 Demeyer DI, Van Nevel CJ. Methanogenesis, an integrated part of carbohydrate fermentation, and its control. In: McDonald IW, Warner ACI, eds. Digestion and metabolism in the ruminant. Proceedings of the IV International Symposium on Ruminant Physiology. University of New England Publishing Unit, 1975: $367-82$.

2 Cummings JH. Fermentation in the human large intestine: evidence and implications for health. Lancet 1983; i: 1206-9.

3 Nottingham PM, Hungate RE. Isolation of methanogenic bacteria from feces of man. J Bacteriol 1968; 96: 2178-9.

4 Miller TL, Wolin MJ, Macario EC de, Macario AJL. Isolation of Methanobrevibacter smithii from human feces. Appl Env Microbiol 1982; 43: 227-32.

5 Miller TL, Wolin MJ. Stability of Methanobrevibacter smithii populations in the microbial flora excreted from the human large bowel. Appl Env Microbiol 1983; 45: 317-8.

6 Weaver GA, Krause JA, Miller TL, Wolin MJ. Incidence of methanogenic bacteria in a sigmoidoscopy population: an association of methanogenic bacteria and diverticulosis. Gut 1986; 27: 698-704.

7 Misawa H, Hoshi T, Kitame F, Homma M, Nakamura $\mathrm{K}$. Isolation of an antigenically unique methanogen from human feces. Appl Env Microbiol 1986; 51: 429-31. 
8 Bjorneklett A, Jenssen E. Relationships between hydrogen $\left(\mathrm{H}_{2}\right)$ and methane $\left(\mathrm{CH}_{4}\right)$ production in man. Scand J Gastroenterol 1982; 17: 985-92.

9 Levitt MD, Ingelfinger FJ. Hydrogen and methane production in man. Ann NY Acad Sci 1968; 150: 75-81.

10 Bond JH, Engel RR, Levitt MD. Factors influencing pulmonary methane excretion in man. An indirect method of studying the in situ metabolism of the methane-producing colonic bacteria. J Exp Med 1971; 133: $572-88$.

11 Pitt P, de Bruijn KM, Beeching MF, Goldberg E, Blendis LM. Studies on breath methane: the effect of ethnic origins and lactulose. Gut 1980; 21: 951-9.

12 McKay LF, Brydon WG, Eastwood MA, Smith JH. The influence of pentose on breath methane. Am J Clin Nutr 1981; 34: 2728-33.

13 Haines A, Metz G, Dilawari J, Blendis L, Wiggins H. Breath-methane in patients with cancer of the large bowel. Lancet 1977; ii: 481-3.

14 Pique JM, Pallares M, Cuso E, Vilar-Bonet J, Gassull MA. Methane production and colon cancer. Gastroenterology 1984; 87: 601-5.

15 McKay LF, Eastwood MA, Brydon WG. Methane excretion in man - a study of breath, flatus and faeces. Gut 1985; 26: 69-74.

16 Flatz G, Czeizel A, Metneki J, Flatz SD, Kuhnau W, Jahn D. Pulmonary hydrogen and methane excretion following ingestion of an unabsorbable carbohydrate: a study of twins. J Pediatr Gastroenterol Nutr 1985; 4: 936-41.

17 Peled Y, Gilat T, Liberman E, Bujanover Y. The development of methane production in childhood and adolescence. J Pediatr Gastroenterol Nutr 1985; 4: 575-9.

18 Calloway DH, Murphy EL. The use of expired air to measure intestinal gas formation. Ann NY Acad Sci 1968; 50: 82-95.

19 Drasar BS, Tomkins AM, Wiggins H, Hudson M. Breath methane levels and intestinal methanogenesis among rural Nigerians on a local diet [Abstract]. Proc Nutr Soc 1984; 43: 86A.

20 Stephen AM, Wiggins HS, Englyst HN, Cole TJ, Wayman BJ, Cummings JH. The effect of age, sex and level of intake of dietary fibre from wheat on large bowel function in thirty healthy subjects. Br J Nutr 1986; 56: 349-61.

21 Higginson J, Oettle AG. Cancer incidence in the Bantu and 'Cape Colored' races of South Africa: Report of a cancer survey in the Transvaal (1953-55). J Natl Cancer Inst 1960; 24: 589-671.

22 Oettlé AG. Cancer in Africa, especially in regions south of the Sahara. J Natl Cancer Inst 1964; 33: 383-439.

23 Walker ARP, Walker BF, Richardson BD, Woolford A. Appendicitis, fibre intake and bowel behaviour in ethnic groups in South Africa. Postgrad Med J 1973; 49: 243-9.

24 Segal I, Solomon A, Hunt JA. Emergence of diverticular disease in the urban South Africa Black. Gastroenterology 1977; 72: 215-9.

25 Pomare EW, Branch WJ, Cummings JH. Carbohydrate fermentation in the human colon and its relation to acetate concentrations in venous blood. $J$ Clin Invest 1985; 75: 1448-54.

26 Union Internationale contre le Cancer (UICC). In: Doll $\mathrm{R}$, Payne $\mathrm{P}$, Waterhouse $\mathrm{J}$, eds. Cancer incidence in five continents, vol I. Heidelberg: Springer-Verlag, 1966.

27 Union Internationale contre le Cancer (UICC). In: Doll $\mathrm{R}$, Muir $\mathrm{C}$, Waterhouse $\mathrm{J}$, eds. Cancer incidence in five continents. Part II. Heidelberg: Springer-Verlag, 1970.

28 Segal I, Cooke SAR, Hamilton DG, Tim LOU. Polyps and colorectal cancer in South African blacks. Gut 1981; 22: 653-7.

29 Bradshaw E, Harington JS. The changing pattern of cancer mortality in South Africa, 1949-1969. S Afr Med J 1975; 49: 919-25.

30 Botha JL, Bradshaw D. African vital statistics - a black hole? S Afr Med J 1985; 87: 977-81.

31 Isaacson C, Selzer G, Kaye V. Cancer in the Urban Blacks of South Africa. S Afr Cancer Bull 1978; 22: 49-84.

32 Bremner CG, Ackerman LV. Polyps and carcinoma of the large bowel in the South African Bantu. Cancer 1970; 26: 991-9.

33 Burkitt DP. Epidemiology of cancer of the colon and rectum. Cancer 1971; 28: 3-13.

34 City of Durban Annual Report of the City Medical Officer of Health 1983.

35 Higginson J, Oettlé AG. Cancer incidence in the South Africa Bantu: Johannesburg (1953-1955). Age specific rates with direct standardisation to a standard African population. S Afr Med Sci 1966; 31: 21-41.

36 Sutherland JC. Cancer in a mission hospital in South Africa. Cancer 1968; 22: 372-8.

37 OPCS Monitor, DH2 87/1. Deaths by cause. Office of Population Censuses \& Surveys, March 1987.

38 International Agency for Research on Cancer. In:

Waterhouse J, Muir C, Correa P, Powell J, eds. Cancer incidence in five continents, Vol III. IARC Scientific Publications No 15. Lyon: IARC, 1976.

39 Waterhouse J, Shanmugaratnam K, Muir C, Powell J. Cancer Incidence in Five Continents, Vol IV (IARC Scientific Publications No 42). Lyons: International Agency for Research on Cancer, 1982.

40 Haines AP, Imeson JD, Wiggins HS. Relation of breath methane with obesity and other factors. Int $J$ Obesity 1984; 8: 675-80.

41 McBee RH. Metabolic consequences of the caecal flora. Am J Clin Nutr 1970; 23: 1514-8.

42 Mah RA, Ward DM, Baresi L, Glass TC. Biogenesis of methane. Ann Rev Microbiol 1977; 31: 309-41.

43 McKay LF, Holbrook WP, Eastwood MA. Methane and hydrogen production by human intestinal bacteria. Acta Path Microbiol Immunol Scand B 1982; 90: 257-60.

44 Allison C, Macfarlane GT. Dissimilatory $\mathrm{NO}_{3}$ reduction by human large intestinal bacteria. Abstracts of 106th Meeting of Soc Gen Microbiol 1986: 80.

45 Burkitt DP, Walker ARP, Painter NS. Effect of dietary fibre on stools and transit times, and its role in the causation of disease. Lancet 1972; ii: 1408-12.

46 Walker ARP, Gajjar D. Gastro-intestinal transit time and serum lipid levels in Black schoolchildren. $S$ Afr Med J 1977; 52: 677-9. 